pterylographers the world round knew of those little naked places over the tops of the eyes in swifts. Personally, I have yet to find a hummingbird wherein the skin covering the pinion is black, and as this communication goes to press, I have examined an excellent specimen of Trochilus colubris, and it possesses no such character. Everyone knows, who knows anything of the subject at all, that it is present in swifts.

6th January, 1906.

R. W. Shufeldt.

\title{
A Suggestion.
}

To the Editors of 'The Auk':-

Dear Sirs: - During the revision of the A. O. U. Check-List I trust that the common names will not be entirely neglected. Most of the names in the last edition are well chosen and have stood the test of time, but a few appear to be either inappropriate or else a trifle bookish. As an example of a 'bookish' name the word "partridge" may be eited. Neither ornithologists or sportsmen employ this word in the A. O. U. sense. In speaking of species of Oreortyx, Lophortyx, Callipepla, and Cyrtonyx, they, of course, use "quail." Our western members may not know that Bonasa is commonly called "partridge" from New England to Pennsylvania, while the same name is applied to Colinus in the South. Hence we have a curious confusion of terms. I wish to propose that "quail" be substituted for "partridge" in the next check-list. I have heard the objection raised that these birds are not true quail, but as they are not true partridges, this fact may be cheerfully overlooked.

Names which can be improved upon are such as Louisiana Tanager, Arkansas Kingbird, Arkansas Goldfinch, and possibly a few others with inappropriate geographical handles. Western Tanager has been in literature for fifteen years and is a better name. I leave the others to the tender mercies of a committee.

In California the Mountain Quail of nearly all sportsmen and bird men is Oreortyx pictus plumiferus, called Plumed Partridge in the Check-List. Why not change things about and call pictus, Harlequin or Painted Quail, and place Mountain Quail where it belongs? Geographical names are becoming more popular (and are more useful) than personal names. Hence we now frequently see Sierra Junco, instead of Thurber Junco. This commendable practice could be extended advantageously. Mr. Grinnell in describing Parus rufescens barlowi had to rename neglectus, which he called Marin Chickadee. Mr. Ridgway has unfortunately discarded this for Nicasio Chickadee - unfortunately, because Nicasio is only a very little town that is not likely to last a great while, whereas Marin County, California, covers most of the range of neglectus. There are other slight changes, "mere details" perhaps, but wise men tell us that only through attention to details shall we arrive at perfection.

My idea has been to make the suggestion rather than to furnish specific cases for its application.

Stanford University, Cal.

Walter K. Fisher. 


\section{$2 \mathrm{BHL}$ Biodiversity Heritage Library}

Fisher, Walter K. 1906. "A Suggestion." The Auk 23, 245-245.

https://doi.org/10.2307/4070789.

View This Item Online: https://www.biodiversitylibrary.org/item/54325

DOI: https://doi.org/10.2307/4070789

Permalink: https://www.biodiversitylibrary.org/partpdf/86112

\section{Holding Institution}

Smithsonian Libraries

\section{Sponsored by}

Smithsonian

\section{Copyright \& Reuse}

Copyright Status: Public domain. The BHL considers that this work is no longer under copyright protection.

This document was created from content at the Biodiversity Heritage Library, the world's largest open access digital library for biodiversity literature and archives. Visit BHL at https://www.biodiversitylibrary.org. 